\title{
Electronic nicotine delivery systems (ENDS): the beginning of the end or the end of the beginning?
}

\author{
Francesco Blasi ${ }^{1}$ and Brian Ward ${ }^{2}$
}

Affiliations: ${ }^{1}$ Dept of Pathophysiology and Transplantation, University of Milan, IRCCS Fondazione Cà Granda Milano, Milan, Italy. ${ }^{2}$ European Affairs Dept, European Respiratory Society, Brussels, Belgium.

Correspondence: Francesco Blasi, Dept of Pathophysiology and Transplantation, University of Milan, IRCCS Fondazione Cà Granda Milano, Via Francesco Sforza 35, 20122 Milan, Italy. E-mail: francesco.blasidunimi.it

@ERSpublications

ERS is opposed to the use of unregulated electronic nicotine delivery systems http://ow.ly/z2pfV

5 million people in the world die of active smoking and more than 600000 nonsmokers die from exposure to passive smoke annually [1]. Smoking is recognised as one of the major preventable causes of death. It significantly increases the chances of developing a respiratory disorder and over half of respiratory diseaserelated deaths are due to smoking [2,3]. One of the key points in the fight against the tobacco epidemic is to encourage as many smokers as possible to quit [4]. The emergence of electronic nicotine delivery systems (ENDS), or electronic (e)-cigarettes, presents complex considerations in this context. E-cigarettes have been subject to regulatory, legal and evidentiary gaps, and they have been met with contrasting reaction from public health experts, clinicians, scientists and governments [5-10]. Some focus strongly on the benefits of these products based on the available evidence while others highlight the risks, also based on the evidence. In certain assessments, they are the beginning of the end for tobacco use, while in others, they herald a new public health threat $[11-14]$.

\section{Benefits}

It is argued that e-cigarettes and other novel nicotine devices could provide an effective alternative to conventional cigarettes. The case for the potential benefit is that e-cigarettes could lead to a significant decrease in the prevalence of smoking, prevent many deaths and episodes of serious illness, and help to reduce health inequalities that tobacco smoking currently exacerbates [15]. Moreover, e-cigarettes do not involve the combustion of tobacco, and hence are less likely to pose a direct hazard to the user. If used instead of cigarettes, they could possibly lower risks of tobacco related morbidity and mortality [16].

\section{Risks}

Adverse health effects, their potential to promote continued addictive nicotine use and renormalisation of smoking are the principal risks of e-cigarettes [17, 18]. While short-term health effects have been shown, and appear not as great as the impact of tobacco, the adverse health effects on the long term are not yet known [19-22]. E-cigarettes could undermine prevention and cessation of tobacco. As they become increasingly widely available and are widely marketed, particularly to the young, they could become the main gateway both to tobacco smoking and nicotine dependence [23].

\section{Strong regulatory framework, independent research and transparency}

At the international level, the World Health Organization (WHO) has looked into options for the regulation of e-cigarettes and the conference of the parties to the WHO Framework Convention on Tobacco

Received: July 072014 | Accepted: July 082014

Conflict of interest: Brian Ward is an employee of the European Respiratory Society. 
Control will discuss these further in October 2014 [24, 25]. Furthermore, in the context of the United Nations actions on noncommunicable diseases, the Forum of International Respiratory Societies has issued a statement on e-cigarettes [26]. The European Respiratory Society (ERS) has recently been involved in debates about regulation at the European Union (EU) level.

ERS is opposed to the use of unregulated ENDS. While e-cigarettes have potential health benefits, a strong regulatory framework is required, particularly to protect children and young adults. ERS maintains that there is a clear need for further independent research to find out both the potential benefits and risks of these products. These studies should be independent clinical trials, behavioural and psychological studies, and postmarketing studies at individual and population levels. ERS supports the existing Article 14 guidelines of the WHO Framework Convention on Tobacco Control, which state that countries should prioritise cessation treatments "strongly based" on scientific evidence [27].

On a separate point, ERS is also strongly in favour of transparency and, in addition to a strong conflict-ofinterest policy for relations with the tobacco industry [28], it has recently also adopted a policy that includes the declaration of studies or activities funded by e-cigarette manufacturers. It is important that commercially driven research on nicotine delivery systems is clearly declared and identifiable.

\section{The debate in Europe}

In its proposal for a revision of the Tobacco Products Directive, the European Commission proposed regulating e-cigarettes as medicines [29]. Prohibition of e-cigarettes was not proposed as an option by the Commission nor suggested by parliamentarians, although it is the form of regulation favoured by several countries [26]. ERS agreed with the European Commission proposal that e-cigarettes should be subject to control and regulated as medicines [30]. Furthermore, ERS explained in the hearing at the European Parliament that the long term effects of e-cigarettes are unknown. Concerning this lack of knowledge, ERS stated that when scientific evidence is insufficient, inconclusive or uncertain, leading to reasonable grounds for concern, with potentially dangerous effect on humans, the precautionary principle should be applied [31]. However, the debate was mostly skewed towards the potential benefits of these emerging products and, although some precautions were proposed, the potential dangerous effects were not considered high enough by regulators to fully invoke the precautionary principle [32-34]. The process of the legislation through the European Council and European Parliament did not change this. The form of regulation did change though, from medicines (more restrictive) as originally proposed by the Commission to consumer products (less restrictive) as proposed by the European Parliament.

\section{The post-2016 regimen}

The final EU Tobacco Products Directive, which was concluded in May 2014 and needs to be implemented by EU countries by 2016, puts in place new rules to regulate and introduce certain precautions on e-cigarettes [35]. There will be a maximum nicotine volume for e-cigarettes $(2 \mathrm{~mL}$ for single use and $10 \mathrm{~mL}$ for refillable cartridges), and a maximum nicotine concentration for refillable cartridges, tanks and containers of nicotine liquids $\left(20 \mathrm{mg} \cdot \mathrm{mL}^{-1}\right)$. Devices with higher concentrations must be approved under a pharmaceutical framework. E-cigarettes will have to be child- and tamper-proof, and protected against leakage to limit the risk of exposure due to handling or ingestion. Only ingredients of high purity may be used in the nicotine-containing liquid and e-cigarettes will be required to deliver the nicotine doses at consistent levels under normal conditions of use.

Health warnings on e-cigarette packs will be mandatory, as will instructions for their use, information on addictiveness and toxicity, a list of all substances contained in the product, and information on the product's nicotine content. No promotional elements will be allowed on packs. Crucially, authorities will monitor the market for any evidence that e-cigarettes lead to nicotine addiction or to traditional tobacco consumption, especially in young people and nonsmokers, and the Commission will report on safety concerns and market developments. There are therefore many research possibilities built into the mechanisms of the Directive and this is to be welcomed.

E-cigarettes on the market will include information on the manufacturer, the ingredients used and emissions, nicotine dose and uptake, product and production process, and a declaration that the manufacturer takes full responsibility for the quality and safety of the product under normal use. Manufacturers will report annually to countries on the sales volumes of the products, types of users, and their preferences and trends. Importantly, existing rules for cross-border advertising and promotion of tobacco products will also apply to e-cigarettes. Where the placing on the market of specific e-cigarettes has been prohibited in three countries, the Commission shall be empowered to extend such a prohibition to all countries in the EU, if such an extension is justified and proportionate. 


\section{The beginning ENDS}

Around 10 years after their introduction to the market, it is clear that we have reached the end of the dramatic introduction of e-cigarettes. Evidence has emerged both of benefits and risks, and positions have been taken for and against. In Europe, the first episode has concluded, yet the only thing known for certain is that we do not know how the series ends.

\section{References}

1 World Health Organization. Tobacco Factsheet. Fact sheet $\mathrm{N}^{\circ} 339$. www.who.int/mediacentre/factsheets/fs339/en/ Date last accessed: July 7th, 2014. Date last updated: May 14, 2014.

2 Gibson GJ, Loddenkemper R, Sibille Y, et al., eds. European Lung White Book. 2nd Edn. Sheffield, European Respiratory Society, 2013.

Ward B. www.smokehaz.eu - a review of the evidence on smoking and lung health. Eur Respir J 2014; 44: $20-22$. WHO Tobacco Free Initiative. MPower. www.who.int/tobacco/mpower/offer/en/ Date last accessed: July 7, 2014. Abrams D, Axéll T, Bartsch P, et al. Statement from specialists in nicotine science and public health policy: reducing the toll of death and disease from tobacco - tobacco harm reduction and the Framework Convention on Tobacco Control (FCTC). http://nicotinepolicy.net/documents/letters/MargaretChan.pdf Date last accessed: July 7, 2014.

6 Action on Smoking and Health. ASH briefing: electronic cigarettes (also known as vaporisers). www.ash.org.uk/ files/documents/ASH_715.pdf Date last accessed: July 7, 2014. Date last updated: June 2014.

7 Glantz S. 129 public health and medical authorities from 31 countries write to WHO DG Chan urging evidencebased approach to ecigs. http://tobacco.ucsf.edu/129-public-health-and-medical-authorities-31-countries-writewho-dg-chan-urging-evidence-based-appro Date last accessed: July 7, 2014. Date last updated: June 16, 2014.

8 US Food and Drug Administration. FDA news release: FDA proposes to extend its tobacco authority to additional tobacco products, including e-cigarettes. www.fda.gov/NewsEvents/Newsroom/PressAnnouncements/ucm394667. htm Date last accessed: July 7, 2014. Date last updated: April 24, 2014.

9 Torjesen I. E-cigarettes are to be regulated as medicines from 2016. BMJ 2013; 346: f3859.

10 Health Sciences Authority. Highlights: prohibition on certain products. www.hsa.gov.sg/publish/hsaportal/en/ health_products_regulation/tobacco/legislation/highlights__prohibition.html Date last accessed: July 7, 2014 Date last updated: December 2, 2013.

11 McArdle M. E-cigarettes: a \$1.5 billion industry braces for FDA regulation. www.businessweek.com/articles/2014 02-06/e-cigarettes-fda-regulation-looms-for-1-dot-5-billion-industry Date last accessed: July 7, 2014. Date last updated: February 6, 2014.

12 Chapman S. Simon Chapman on e-cigarettes: the best and the worst case scenarios for public health. http://blogs. bmj.com/bmj/2014/03/14/simon-chapman-on-e-cigarettes-the-best-and-the-worst-case-scenarios-for-public-health/ Date last accessed: July 7, 2014. Date last updated: March 14, 2014.

13 Chapman S. Should electronic cigarettes be as freely available as tobacco cigarettes? No. BMJ 2013; 346: f3840.

14 Etter JF. Should electronic cigarettes be as freely available as tobacco? Yes. BMJ 2013; 346: f3845.

15 Royal College of Physicians. RCP statement on electronic cigarettes. https://www.rcplondon.ac.uk/press-releases/ rcp-statement-e-cigarettes Date last accessed: July 7, 2014. Date last updated: June 25, 2014.

16 Vardavas CI, Filippidis FT, Agaku IT. Determinants and prevalence of e-cigarette use throughout the European Union: a secondary analysis of 26566 youth and adults from 27 countries. Tob Control 2014; DOI: 10.1136/ tobaccocontrol-2013-051394.

17 Utah Dept of Health. Utah health status update: electronic cigarette use among Utah students (grades 8, 10, and 12) and adults. http://health.utah.gov/opha/publications/hsu/1312_ECig.pdf Date last accessed: July 7, 2014. Date last updated: December, 2013.

18 Dutra LM, Glantz SA. Electronic cigarettes and conventional cigarette use among US adolescents: a cross-sectional study. JAMA Pediatr 2014; 168: 610-617.

19 Goniewicz ML, Knysak J, Gawron M, et al. Levels of selected carcinogens and toxicants in vapour from electronic cigarettes. Tob Control 2013; 23: 133-139.

20 Flouris AD, Chorti MS, Poulianiti KP, et al. Acute impact of active and passive electronic cigarette smoking on serum cotinine and lung function. Inhal Toxicol 2013; 25: 91-101.

21 Vardavas CI, Anagnostopoulos N, Kougias M, et al. Short-term pulmonary effects of using an electronic cigarette: impact on respiratory flow resistance, impedance, and exhaled nitric oxide. Chest 2012; 141: 1400-1406.

22 Vakkalanka JP, Hardison LS Jr, Holstege CP. Epidemiological trends in electronic cigarette exposures reported to U.S. Poison Centers. Clin Toxicol 2014; 52: 542-548.

23 Grana R, Benowitz N, Glantz SA. E-cigarettes: a scientific review. Circulation 2014; 129: 1972-1986.

24 World Health Organization FCTC. Electronic nicotine delivery systems, including electronic cigarettes. http://apps. who.int/gb/fctc/PDF/cop5/FCTC_COP5_13-en.pdf Date last accessed: July 7, 2014. Date last updated: June 18, 2012.

25 World Health Organization FCTC. Conference of the Parties to the WHO Framework Convention on Tobacco Control Sixth session Moscow, Russian Federation, 13-18 October 2014. www.who.int/fctc/cop/sessions/ COP6_1_Provisonal_Agenda_EN.pdf?ua=1.

26 Schraufnagel DE, Blasi F, Drummond MB, et al. Electronic cigarettes: a position statement of the Forum of International Respiratory Societies. www.firsnet.org/images/firs/pdf/FIRS_E-cigarettes_position_statement_final. pdf Date last accessed: July 14, 2014. Date last updated: July 10, 2014.

27 World Health Organization FCTC. Guidelines for implementation of Article 14 of the WHO Framework Convention on Tobacco Control. www.who.int/fctc/Guidelines.pdf Date last accessed: July 7, 2014. Date last updated: November 2010.

28 Rabe RF, Gratziou C, Ward B, et al. Towards a total ban on links with the tobacco industry: new rules for the ERS. Eur Respir J 2012; 40: 809-810.

29 European Commission. Revision of the tobacco products directive. http://ec.europa.eu/health/tobacco/products/ revision/ Date last updated: 2014 
European Respiratory Society. ERS position on the Revision of the Tobacco Products Directive. www.ersnet.org/ ers-position-on-the-revision-of-the-tobacco-products-directive.html Date last accessed: July 7, 2014.

31 European Parliament. Electronic cigarettes. www.europarl.europa.eu/document/activities/cont/201307/20130717ATT 69885/20130717ATT69885EN.pdf Date last accessed: July 7, 2014. Date last updated: May, 2013.

32 European Commission. Communication from the Commission on the precautionary principle. http://eur-lex. europa.eu/LexUriServ/LexUriServ.do?uri=COM:2000:0001:FIN:EN:PDF Date accessed: July 7, 2014.

33 Chaffin J, Robinson D. E-cigarettes exhale sigh of relief on EU regulation. www.ft.com/intl/cms/s/0/e4c97f3c-302b11e3-80a4-00144feab7de.html\#axzz36nBc7XQO Date last accessed: July 7, 2014. Date last updated: October 8, 2013.

34 European Parliamentary Research Service. New Rules on Electronic Cigarettes. http://epthinktank.eu/2014/03/11/ new-rules-on-electronic-cigarettes/ Last accessed: July $7^{\text {th }}, 2014$. Date last updated: March 11, 2014.

35 European Union. Directive 2014/40/EU of the European Parliament and of the Council. Off J Eur Union 2014; L127: 1-38. 